\title{
Penggunaan Media pada Pembelajaran Daring Tema 7 "Peristiwa dalam Kehidupan" Kelas V di SDN Sumbersari 1 Malang
}

\author{
Mar'atus Sholichah*, Sri Estu Winahyu, Sukamti \\ Universitas Negeri Malang, Jl. Semarang No. 5 Malang, Jawa Timur, Indonesia \\ *Penulis korespondensi, Surel: sholichahmaratus20@gmail.com
}

Paper received: 7-6-2021; revised: 21-6-2021; accepted: 28-6-2021

\begin{abstract}
Learning media is one of the important components in learning. Before using the media the teacher must pay attention to the planning and criteria for selecting a good media. So that the desired learning objectives can be achieved optimally. However, not all teachers plan, select, and use learning media properly and appropriately. This study aims to describe the planning, selection, and use of media as well as the obstacles experienced in implementing the use of media in online learning Theme 7 "Events in Life" Fifth Grade at State Elementary School Sumbersari 1 Malang. This study uses a descriptive qualitative approach. Collecting data using interview, observation, and documentation techniques. Based on the results of the study, it was found that the teacher did not do the media planning themselves but used the media planning listed in the lesson plans which were arranged in one cluster. In choosing the media, it is different from the media that has been planned. This is because the media planned in the lesson plans cannot be applied 100 percent the same, adjusting to the conditions of each school. There are media that are not in accordance with the learning objectives. The use of media has implemented the steps of using media well. The obstacle experienced is that there are students who do not open the media sent by the teacher. As well as the limited ability of teachers in making technology-based media.
\end{abstract}

Keywords: media use; online learning; elementary school

\begin{abstract}
Abstrak
Media pembelajaran merupakan salah satu komponen penting dalam pembelajaran. Sebelum menggunakan media guru harus memperhatikan perencanaan dan kriteria pemilihan media yang baik. Sehingga tujuan pembelajaran yang diinginkan dapat tercapai dengan optimal. Namun, tidak semua guru melakukan perencanaan, pemilihan, dan penggunaan media pembelajaran dengan baik dan sesuai. Penelitian ini bertujuan untuk mendeskripsikan perencanaan, pemilihan, dan penggunaan media serta kendala yang dialami dalam penerapan penggunaan media pada pembelajaran daring Tema 7 "Peristiwa dalam Kehidupan" kelas V di SDN Sumbersari 1 Malang. Penelitian ini menggunakan pendekatan kualitatif deskriptif. Pengumpulan data menggunakan teknik wawancara, observasi, dan dokumentasi. Berdasarkan hasil penelitian diperoleh bahwa guru tidak melakukan perencanaan media sendiri melainkan menggunakan perencanaan media yang tertera pada dokumen RPP yang disusun dalam satu gugus. Dalam memilih media, berbeda dengan media yang sudah direncanakan. Hal ini dikarenakan media yang direncanakan dalam RPP tidak bisa diterapkan 100 persen sama, menyesuaikan dengan kondisi sekolah masing-masing. Terdapat media yang tidak sesuai dengan tujuan pembelajaran. Penggunaan media sudah menerapkan langkahlangkah penggunaan media dengan baik. Kendala yang dialami yaitu terdapat siswa yang tidak membuka media yang dikirimkan oleh guru. Serta keterbatasan kemampuan guru dalam membuat media berbasis teknologi.
\end{abstract}

Kata kunci: penggunaan media; pembelajaran daring; sekolah dasar 


\section{Pendahuluan}

Semenjak masa pandemi Covid-19 pemerintah telah membuat kebijakan seperti wajib menggunakan masker, jaga jarak atau social and physical distancing, work from home (WFH), dan study from home (SFH). Kondisi ini membuat perlunya dilakukan inovasi, khususnya di bidang pendidikan. Salah satu inovasi tersebut yaitu dengan melakukan pembelajaran jarak jauh. Pembelajaran jarak jauh dibagi menjadi 2 pendekatan. Kedua pendekatan ini yaitu pembelajaran jarak jauh dalam jaringan/online (daring) menggunakan gawai (gadget) atau laptop melalui portal dan aplikasi pembelajaran daring, serta pembelajaran jarak jauh luar jaringan/offline (luring) menggunakan televisi, radio, modul belajar, bahan ajar cetak, lembar kerja, media atau alat peraga benda di lingkungan sekitar (Gusty, dkk., 2020). Pembelajaran daring secara otomatis melibatkan media pembelajaran.

Media pembelajaran merupakan faktor penting dalam ketercapaian suatu tujuan pembelajaran. Apabila guru mampu memanfaatkan sumber dan media pembelajaran sesuai dengan tuntutan kurikulumnya maka akan menghasilkan pembelajaran yang efektif (Akbar, 2013). Pemilihan media pembelajaran sangat mempengaruhi keberhasilan pelaksanaan pembelajaran. Guru sebelum melakukan pemilihan media hendaknya melakukan perencanaan penggunaan media pembelajaran untuk menjamin pembelajaran yang efektif. Namun, belum semua guru melaksanakan perencanaan, pemilihan, dan penggunaan media pembelajaran yang baik dan sesuai. Heinich dkk. (1982) dalam Arsyad (2017) menyusun suatu model untuk menjamin perencanaan penggunaan media pembelajaran yang efektif, model ini diberi nama akronim "ASSURE" yang terdiri dari 6 langkah perencanaan sistematik penggunaan media meliputi: Analyze Learner Characteristics, State Objectives, Select, Modify or Design Materials, Utilize Materials, Require Learner Response, dan Evaluate. Keenam kegiatan utama perencanaan pembelajaran dalam model ini perlu diperhatikan untuk menjamin penggunaan media pembelajaran yang efektif.

Pemilihan media dalam pembelajaran dilakukan dengan mempertimbangkan kriteria pemilihan media agar sesuai dengan tujuan yang diharapkan. Kriteria pertama yaitu kesesuaian dengan tujuan. Media dipilih berdasarkan tujuan instruksional yang secara umum mengacu pada ranah kognitif, afektif, dan/atau psikomotorik (Musfiqon, 2016). Guru harus memahami betul tujuan media pembelajaran itu digunakan agar pembelajaran tetap terarah. Kriteria yang kedua yaitu sesuai dengan karakteristik siswa/sasaran. Misalkan dalam kelas tersebut gaya belajar siswa tergolong tipe auditif-visual, media yang digunakan juga berbasis audio-visual (Abidin, 2017). Kriteria ketiga yaitu ketersediaan sumber, dana, tenaga, dan fasilitas. Apabila media yang akan digunakan tidak/sulit ditemukan pada sumber yang ada, maka media harus dibuat atau dibeli sendiri (Sadiman, dkk., 2011). Kriteria keempat yaitu keterampilan guru dalam menggunakan media yang dipilih. Apapun media yang dipilih, guru harus mampu menggunakannya dalam proses pembelajaran dengan lancar. Kriteria yang kelima yaitu mutu teknis media. Media yang dipilih dan digunakan sebaiknya memiliki mutu teknis yang baik (Musfiqon, 2016). Misalnya pada media visual, media visual yang digunakan harus jelas, informasi dan pesan yang ingin disampaikan tidak boleh terganggu oleh elemen lain.

Terdapat beberapa langkah dalam penggunaan media yang harus diperhatikan agar media dapat digunakan secara efektif dan efisien. Terdapat tiga langkah penggunaan media pembelajaran yaitu (1) persiapan sebelum menggunakan media, (2) kegiatan selama menggunakan media, serta (3) kegiatan tindak lanjut (Sadiman, dkk., 2011). 
Berdasarkan hasil observasi saat melakukan KPL di SDN Sumbersari 1 Malang, ada beberapa guru yang belum maksimal dalam menggunakan media yang tersedia di sekolah. Contohnya saat pembelajaran luring dengan beberapa siswa kelas V, guru menggunakan media seadanya yang ada di buku siswa saat menyampaikan materi tentang organ pernapasan. Siswa masih kesulitan untuk memahami penjelasan guru. Hal ini dibuktikan saat guru melakukan tanya jawab dengan siswa, siswa tidak dapat menjawab pertanyaan yang diberikan. Sehingga guru belum merencanakan dengan baik pemilihan media yang akan digunakan dalam pembelajaran. Dikarenakan kondisi pandemi Covid-19 yang terjadi di area sekolah, pembelajaran luring ini dihentikan. Pada bulan September 2020 hingga April 2021 pembelajaran secara penuh dilakukan dengan pembelajaran daring/online.

Selama pembelajaran daring juga diperlukan media yang bervariasi namun dengan karakteristik yang berbeda dengan media pembelajaran luring. Guru sudah cukup bervariasi dalam menggunakan media pembelajaran daring. Media yang digunakan berupa gambar, video pembelajaran, dan powerpoint. Namun, peneliti ingin mengetahui lebih dalam apakah guru sudah melaksanakan perencanaan, pemilihan dan penggunaan media yang baik dalam pembelajaran.

Penelitian tentang penggunaan media pembelajaran telah dilakukan oleh Hasnaini (2017) yang berjudul "Analisis Penggunaan Media Berdasarkan Kurikulum 2013 pada Pembelajaran Tema 6 Kelas V SDN Sawojajar 5 Kota Malang". Pada penelitian ini diperoleh perencanaan pemilihan media yang dilakukan oleh guru sudah menerapkan tahap analisis karakter siswa, menentukan tujuan, dan memilih media, dalam pemilihannya kurang sesuai dengan kurikulum 2013. Penerapan media kurang sesuai dengan kriteria penerapan media yang baik, serta kesulitan yang dialami yaitu guru kesulitan menyediakan media yang ideal untuk seluruh siswa dan kesulitan dalam pengadaan media pada setiap pembelajaran.

Penelitian yang terkait selanjutnya dilakukan oleh Amelia (2019) berjudul "Penggunaan Media dalam Pembelajaran Tema 6 Panas dan Perpindahannya Kelas V di SDN Gadingkasri Kota Malang". Dalam penelitian ini diperoleh guru telah melaksanakan perencanaan media pada setiap pembelajaran, sebesar $47 \%$ media yang direncanakan sesuai dengan tujuan pembelajaran, penggunaan media sudah dilakukan dengan variasi penggunaan secara klasikal, kelompok, dan perorangan. Kendala yang dialami yaitu guru kesulitan dalam pengadaan media pembelajaran.

Kedua penelitian di atas menginspirasi peneliti untuk mengetahui lebih dalam mengenai penggunaan media pembelajaran. Perbedaannya terdapat pada aspek perencanaan, pemilihan, dan penggunaan beserta kendala yang dialami guru dalam menggunakan media pembelajaran. Kondisi pembelajaran yang dilakukan dalam penelitian ini juga berbeda, yaitu pada pembelajaran daring.

Penelitian akan dilakukan di SDN Sumbersari 1 Malang dengan berdasarkan fenomena yang peneliti temui di kelas V. Penelitian difokuskan pada penggunaan media pembelajaran dalam Tema 7 "Peristiwa dalam Kehidupan" kelas V SD. Karena, berdasarkan hasil kajian kebutuhan media pada tema 7 , terdapat beberapa pembelajaran yang memerlukan penggunaan media. Terdapat kegiatan percobaan pada muatan IPA di setiap subtema yang membutuhkan penggunaan media. Terdapat materi tentang sifat-sifat benda, peristiwa perubahan wujud benda, serta peristiwa kalor merubah suhu dan wujud benda. Guru dapat 
menggunakan media video simulasi percobaan atau siswa melakukan percobaan di rumah menggunakan media benda-benda yang ada di rumah.

Perencanaan media yang baik dapat membantu pencapaian tujuan pembelajaran secara optimal dan menjadikan pembelajaran lebih efektif. Penggunaan media yang baik dalam pembelajaran perlu diperhatikan agar tujuan yang diharapkan dapat tercapai dengan optimal. Oleh karena itu, perlu dilakukan analisis lebih dalam mengenai penggunaan media pada pembelajaran daring tema 7 "Peristiwa dalam Kehidupan" kelas V SDN Sumbersari 1 Malang.

\section{Metode}

Pendekatan penelitian yang digunakan dalam penelitian ini yaitu pendekatan kualitatif dengan jenis penelitian fenomenologi. Penelitian kualitatif adalah penelitian yang bertujuan untuk memahami fenomena yang dialami oleh subjek penelitian (perilaku, persepsi, motivasi, tindakan) secara holistik dengan cara deskripsi melalui kata-kata dan bahasa (Moleong, 2017). Data yang diperoleh dideskripsikan melalui kata-kata atau pernyataan, sehingga menggunakan penelitian kualitatif deskriptif. Pendekatan kualitatif dengan jenis penelitian fenomenologi dipilih karena penelitian dilakukan pada kondisi objek secara alamiah (apa adanya) dan bertujuan untuk menggambarkan karakteristik suatu fenomena yang terjadi.

Kehadiran penelitian di lapangan dalam penelitian kualitatif bertindak sebagai instrumen sekaligus pengumpul data. Pada penelitian ini, peneliti bertindak sebagai pengamat penuh guna mengetahui perencanaan, pemilihan, penggunaan, hingga kendala yang dialami guru dalam menerapkan media pembelajaran daring tema 7 peristiwa dalam kehidupan kelas V SDN Sumbersari 1 Malang. Lokasi penelitian dilaksanakan di SDN Sumbersari 1 Kota Malang yang beralamatkan di Jalan Sigura-gura I No.11 Kelurahan Sumbersari, Kecamatan Lowokwaru, Kota Malang. Penelitian ini dilaksanakan pada bulan Maret selama pembelajaran tema 7 berlangsung di kelas V SDN Sumbersari 1 Malang.

Sumber data dalam penelitian ini yaitu guru kelas dan siswa kelas V SDN Sumbersari 1 Malang berupa kata-kata dan tindakan yang diperoleh melalui wawancara dan observasi. Dalam penelitian ini digunakan beberapa teknik pengumpulan data yaitu observasi, wawancara, dan dokumentasi. Teknik pengumpulan data observasi dilakukan dengan menganalisis perencanaan media pembelajaran pada RPP yang digunakan. Kegiatan observasi juga dilakukan untuk mengetahui penggunaan dan kendala penerapan media pembelajaran daring di kelas V SDN Sumbersari 1 Malang. Observasi dilakukan saat kegiatan pembelajaran daring melalui grup whatsapp maupun zoom. Kemudian wawancara diajukan kepada guru kelas menggunakan pedoman wawancara tentang perencanaan, pemilihan, penggunaan, dan kendala penerapan media pada pembelajaran daring. Wawancara juga dilakukan dengan 3 siswa kelas $\mathrm{V}$ untuk mengetahui kendala yang dialami selama penggunaan media pembelajaran daring. Data dokumen yang dikumpulkan dalam penelitian ini yaitu dokumen perencanaan media berupa Rencana Pelaksanaan Pembelajaran (RPP) yang digunakan dalam pembelajaran tema 7 untuk mengetahui perencanaan dan pemilihan media. Dokumentasi penggunaan dan kendala penerapan media diperoleh selama pelaksanaan pembelajaran daring berlangsung di kelas V SDN Sumbersari 1 Malang.

Pengecekan keabsahan data penelitian dilakukan dengan meningkatkan ketekunan, triangulasi teknik dan sumber, serta menggunakan bahan referensi. Tahap-tahap penelitian dalam penelitian ini meliputi tahap pra lapangan, tahap pekerjaan lapangan, dan tahap analisis data. 


\section{Hasil dan Pembahasan}

\subsection{Perencanaan Media}

Hasil penelitian tentang perencanaan media pada pembelajaran daring diperoleh melalui hasil wawancara dan analisis dokumen perencanaan media pada RPP yang digunakan oleh guru kelas V SDN Sumbersari 1 Malang. Dari 18 dokumen perencanaan media yang harus disusun dalam satu tema, hanya terdapat 13 dokumen perencanaan dan bukan merupakan hasil sendiri melainkan dari KKG segugus. Berdasarkan hasil wawancara dengan guru kelas V SDN Sumbersari 1, perencanaan media pembelajaran yang digunakan diperoleh dari KKG (Kelompok Kerja Guru) Gugus 4 Kecamatan Lowokwaru Kota Malang. Hal ini merupakan hasil dari kesepakatan gugus, dokumen perencanaan media dalam RPP boleh digunakan boleh tidak ataupun direvisi sendiri.

Terhitung sejak bulan maret 2020 pembelajaran sudah dilaksanakan secara daring, seharusnya didukung dengan perencanaan media yang sudah disesuaikan dengan kondisi pembelajaran daring. Dari 13 dokumen perencanaan media yang disusun, hanya terdapat 6 dokumen perencanaan media pembelajaran daring yaitu pada subtema 3 pembelajaran 1 sampai 6. Terdapat pembelajaran yang masih mengadopsi dari dokumen perencanaan yang lama. Menggunakan indikator pembelajaran yang masih sama, namun langkah-langkah pembelajarannya hanya diambil beberapa dan disesuaikan kembali dengan kondisi pembelajaran daring.

Pada subtema 1 dan 2 media yang direncanakan kurang bervariasi, hanya menggunakan media yang ada pada buku tema saja berupa teks dan gambar. Pada subtema 3 media yang digunakan bervariasi dan sudah disesuaikan dengan kondisi pembelajaran daring berupa video dan powerpoint pembelajaran.

Terdapat 31 media pembelajaran yang direncanakan pada tema 7. Media yang direncanakan terdiri dari 17 teks bacaan dan 6 media gambar yang tersedia pada buku tema, 5 media benda nyata, 1 media powerpoint, dan 2 media video pembelajaran. Dari 31 media yang direncanakan, $50 \%$ lebih diantaranya merupakan media teks dan gambar yang sudah tersedia pada buku tema.

Berdasarkan data penelitian yang telah diperoleh, guru telah melakukan perencanaan media pada pembelajaran daring tema 7 tetapi kurang maksimal. Pada subtema 1 guru hanya menyusun perencanaan media pada pembelajaran 3 saja. Serta perencanaan media yang digunakan pada subtema 1 dan subtema 2 masih menggunakan dokumen RPP yang lama, sehingga media dan kegiatan pembelajarannya masih belum disesuaikan kembali dengan pembelajaran daring.

Pada kegiatan perencanaan media pembelajaran guru harus memperhatikan beberapa faktor. Menurut Heinich, dkk. dalam Nurseto (2012) tahap perencanaan penggunaan media yang efektif meliputi tahap analyze learner characteristics (identifikasi kebutuhan dan karakteristik siswa), state objectives (perumusan tujuan), select, modify or design materials (memilih, merubah, dan merancang media), utilize materials (perumusan materi), require learner response (pelibatan siswa), serta evaluate (evaluasi). 
Berdasarkan temuan penelitian, pada tahap analyze learner characteristics (identifikasi kebutuhan dan karakteristik siswa) guru sudah melakukan identifikasi kebutuhan media yang tepat untuk siswa kelas V. Namun, guru belum melakukan analisis karakteristik siswa kelas V secara mendalam. Seharusnya guru terlebih dahulu mengetahui karakteristik siswa kelas $\mathrm{V}$ agar dapat merencanakan media yang sesuai dengan karakteristik siswa. Guru dapat melakukan analisis secara umum dan khusus. Hal ini dijelaskan oleh Heinich, dkk. dalam Arsyad (2017), guru dapat terlebih dahulu menganalisis latar belakang sosial ekonomi, budaya, usia, hingga analisis khusus meliputi pengetahuan, keterampilan, dan sikap awal yang dimiliki.

Pada tahap perencanaan media select, modify, or design materials (memilih, merubah, dan merancang media) terdapat media yang tidak sesuai dengan materi pembelajaran yaitu media video subtema 3 pembelajaran 3 hasil modifikasi guru kelas V. Menurut Heinich, dkk. dalam Arsyad (2017) dapat dilakukan modifikasi apabila dirasa materi dan media yang sudah ada tidak cocok dengan tujuan pembelajaran atau sasaran partisipan. Guru kurang cermat dalam melakukan modifikasi media, seharusnya diperhatikan kembali muatan materi yang ada pada media apakah sudah sesuai dengan tujuan pembelajaran yang ingin dicapai atau belum.

Pada tahap require learner response (pelibatan siswa) serta evaluate (evaluasi), guru sudah melakukan perencanaan pelibatan siswa dan evaluasi di dalam perencanaan penggunaan media. Pada kegiatan pembelajaran di dalam dokumen RPP sudah ditemui langkah pembelajaran yang melibatkan siswa, siswa diminta untuk memberikan responnya setelah menyimak video pembelajaran dengan berdiskusi bersama dan mengerjakan lembar kegiatan sebagai bentuk evaluasi. Hal ini seperti yang diungkapkan oleh Heinich, dkk. dalam Arsyad (2017) bahwa guru dapat meminta siswa untuk memberikan respon dan umpan balik terhadap keefektifan proses belajar mengajar. Kemudian melalui kegiatan evaluasi dapat dilihat ketercapaian tujuan pembelajaran dan keefektifan penggunaan media dalam pembelajaran.

\subsection{Pemilihan Media}

Pemilihan media pada pembelajaran daring tema 7 "Peristiwa dalam Kehidupan" kelas V SDN Sumbersari 1 Malang diperoleh dengan menganalisis media yang dipilih berdasarkan angket kriteria pemilihan media yang baik yang diambil dari beberapa sumber rujukan. Kriteria tersebut meliputi kesesuaian dengan tujuan, kesesuaian dengan karakteristik siswa/sasaran, ketersediaan sumber, dana, tenaga, dan fasilitas, keterampilan guru, dan mutu teknis media yang dipilih. Karena keterbatasan waktu bertepatan pada jadwal PTS (penilaian tengah semester) yang dimajukan, pelaksanaan pembelajaran pada tema 7 hanya dapat dilaksanakan sebanyak 8 kali pertemuan saja. Pada 8 kali pertemuan ini guru melakukan pemilihan media sebanyak 6 kali pembelajaran.

Media yang dipilih sudah cukup bervariasi dan tidak hanya menggunakan media yang sudah tersedia pada buku tema saja. Namun, media yang dipilih berbeda dengan media yang sudah direncanakan pada RPP. Guru tidak terlalu berpatokan pada dokumen perencanaan dan media yang dipilih juga disesuaikan kembali dengan keadaan pembelajaran daring. Dokumen perencanaan media dari gugus tidak diterapkan seluruhnya, karena kondisi setiap sekolah berbeda-beda dan tidak dapat disamakan. 
Pemilihan media dalam pembelajaran dengan memperhatikan kriteria-kriteria pemilihan media yang baik dapat membuat media pembelajaran menjadi berkualitas dan sesuai dengan tujuan pembelajaran. Pemilihan media dalam pembelajaran dengan memperhatikan kriteria-kriteria pemilihan media yang baik dapat membuat media pembelajaran menjadi berkualitas dan sesuai dengan tujuan pembelajaran (Suryani, dkk., 2018). Dirujuk dari beberapa sumber, kriteria dalam pemilihan media yang harus diperhatikan meliputi kesesuaian dengan tujuan, karakteristik siswa/sasaran, ketersediaan sumber, dana, tenaga, dan fasilitas, keterampilan guru, serta mutu teknis.

Kriteria yang pertama yaitu kesesuaian dengan tujuan. Dari 6 media yang dipilih pada pembelajaran tema 7 "Peristiwa dalam Kehidupan", terdapat 1 media yang tidak sesuai dengan $\mathrm{KD}$, indikator, dan materi pembelajaran sehingga tidak dapat menunjang pencapaian tujuan pembelajaran. Hal ini menunjukkan bahwa guru sudah memperhatikan kesesuaian antara tujuan dengan media yang dipilih. Media pembelajaran yang dipilih harus disesuaikan dengan tujuan pembelajaran. Arsyad (2017) menyatakan bahwa pemilihan media pembelajaran didasarkan pada tujuan instruksional yang telah ditetapkan dan setidaknya mengacu pada dua dari tiga ranah kognitif, afektif, dan psikomotorik. Hal ini dilakukan agar media yang digunakan dalam pembelajaran dapat terarah dan tidak melenceng dari tujuan.

Kriteria yang kedua yaitu karakteristik siswa/sasaran. Berdasarkan hasil penelitian guru belum memperhatikan karakteristik siswa dalam melakukan pemilihan media. Hal ini dibuktikan pada dokumen perencanaan media yang digunakan oleh guru yaitu menggunakan perencanaan media dari KKG gugus 4 kecamatan lowokwaru. Guru belum mengenal karakteristik siswa kelas $\mathrm{V}$ terlebih dahulu sebelum menyusun perencanaan media. Musfiqon (2016) mengungkapkan bahwa media yang tidak sesuai dengan keadaan siswa/sasaran tidak dapat banyak membantu siswa dalam memahami materi pembelajaran. Sehingga sebelum memilih media, sebaiknya guru terlebih dahulu mengenal karakteristik dan minat siswanya terlebih dahulu agar media yang dipilih dapat membantu siswa dalam memahami materi pembelajaran.

Kriteria pemilihan media yang ketiga yaitu ketersediaan sumber, dana, tenaga, dan fasilitas. Fasilitas utama yang digunakan siswa yaitu smartphone maupun laptop/komputer yang jika dimiliki di rumah masing-masing. Berdasarkan data hasil penelitian, media yang dipilih seperti video dan powerpoint dapat dioperasikan dengan mudah oleh siswa melalui smartphone yang dimiliki di rumah. Alat dan bahan untuk melakukan pengamatan perubahan wujud benda juga mudah diperoleh karena memanfaatkan benda-benda yang ada di rumah. Musfiqon (2016) menyatakan bahwa tidak diperkenankan guru memilih media yang mahal tetapi hasil pembelajaran yang dihasilkan tidak sebanding dengan biaya yang harus dikeluarkan. Media yang dipilih tidak membutuhkan biaya yang besar, memanfaatkan bendabenda di lingkungan sekitar siswa. Hal ini menunjukkan pemilihan media pembelajaran daring tema 7 kelas V SDN Sumbersari 1 Malang sudah memperhatikan ketersediaan sumber, dana, dan fasilitas yang ada.

Kriteria pemilihan media yang keempat yaitu keterampilan guru dalam mengoperasikan media. Guru harus mampu menggunakan media yang dipilih dalam proses pembelajaran. Arsyad (2017) mengungkapkan bahwa media apapun yang dipilih, guru harus dapat menggunakannya. Karena, keterampilan guru dalam menggunakan media berpengaruh pada nilai dan kemanfaatan media dalam pembelajaran. Media yang dipilih oleh guru kelas pada 
pembelajaran daring tema 7 sudah dapat dioperasikan dengan baik. Guru sudah dapat mengirimkan tautan untuk membuka video pembelajaran melalui grup whatsapp.

Kriteria yang kelima yaitu mutu teknis media pembelajaran. Media yang dipilih dan digunakan sebaiknya memiliki mutu teknis yang baik (Musfiqon, 2016). Dalam memilih media pada pembelajaran daring tema 7 , sudah memperhatikan mutu teknis media pembelajaran. Media video pembelajaran dan powerpoint yang dipilih sudah memiliki kualitas yang baik dan layak digunakan dalam pembelajaran. Arsyad (2017) menyatakan, aspek visual pada media harus jelas, informasi dan pesan yang ditampilkan tidak boleh terganggu oleh latar belakang teks. Pada media visual yang dipilih, informasi yang ingin disampaikan sudah jelas dan tidak terganggu oleh elemen lain.

\subsection{Penggunaan Media}

Data penggunaan media pada pembelajaran daring tema 7 "Peristiwa dalam Kehidupan" kelas V di SDN Sumbersari 1 Malang diperoleh melalui observasi penggunaan media dalam pembelajaran daring melalui whatsapp dan kegiatan zoom, dokumentasi kegiatan pembelajaran daring, serta wawancara dengan guru kelas dan 3 siswa kelas V.

Berdasarkan hasil observasi, penggunaan media pada pembelajaran daring tema 7 kelas $\mathrm{V}$ di SDN Sumbersari 1 sudah menerapkan langkah-langkah penggunaan dengan cukup baik. Penggunaan media dalam pembelajaran dapat bervariasi. Dilihat dari variasi penggunaannya, media dapat digunakan secara individu/perorangan, kelompok atau massal (Daryanto, 2013). Pada pembelajaran daring tema 7 ini, media hanya digunakan secara individu/ perorangan. Guru mengirimkan media video pembelajaran melalui pesan whatsapp dan menjelaskan langkah-langkah pembelajaran yang akan siswa lakukan. Sedangkan penggunaan media powerpoint tidak dikirim melalui pesan whatsapp, media powerpoint langsung ditampilkan pada saat kegiatan zoom berlangsung.

Terdapat tiga langkah utama yang harus diikuti dalam menggunakan media agar efektif dan efisien. Ketiga langkah tersebut meliputi persiapan sebelum menggunakan media, kegiatan selama menggunakan media, dan kegiatan tindak lanjut (Sadiman, dkk., 2011). Tahap pertama yaitu persiapan, meliputi persiapan peralatan yang diperlukan dan penempatannya. Tahap persiapan ini sudah muncul dalam penggunaan media pembelajaran daring di kelas $\mathrm{V}$ SDN Sumbersari 1 Malang. Dikarenakan kondisi pembelajaran daring, peralatan utama yang dibutuhkan yaitu smartphone atau komputer serta kuota internet untuk mengakses media pembelajaran. Media alat dan bahan untuk mengamati perubahan wujud benda juga harus dipersiapkan sendiri oleh siswa di rumahnya masing-masing. Selain persiapan peralatan, guru juga mengatur kesiapan siswa untuk belajar. Guru kelas mengirimkan pesan melalui grup whatsapp untuk membimbing siswa melakukan aktivitas sebelum belajar seperti mandi pagi, salat, dan berdoa. Kemudian guru juga memperkenalkan pokok materi yang akan dipelajari oleh siswa kemudian mengirimkan media pembelajaran.

Tahap yang kedua yaitu kegiatan selama menggunakan media. Pada tahap ini hal yang harus diperhatikan yaitu suasana ketenangan dan hal-hal yang dapat mengganggu konsentrasi siswa harus dihindari (Sadiman, dkk., 2011). Berdasarkan hasil temuan penelitian, pada saat kegiatan zoom pembelajaran daring tema 7 kelas $V$ guru masih kurang dalam mengkondisikan siswa. Terdapat siswa yang ramai dengan mengirim pesan pada zoom sehingga membuat siswa lain terganggu. Juga terdapat siswa yang sengaja mencoreti tampilan layar saat guru 
menampilkan powerpoint. Hal ini membuat konsentrasi siswa dalam menyimak penjelasan guru menjadi terganggu.

Tahap yang ketiga yaitu kegiatan tindak lanjut. Kegiatan tindak lanjut sangat berperan penting pada penggunaan media pembelajaran. Pada kondisi pembelajaran daring guru tidak dapat melihat langsung ketercapaian tujuan pembelajaran, sehingga kegiatan tindak lanjut penting dilakukan untuk mengetahui hal tersebut. Dalam Sadiman, dkk. (2011) dijelaskan bahwa maksud dari kegiatan tindak lanjut yaitu untuk menelaah apakah tujuan yang diharapkan telah tercapai. Berdasarkan temuan hasil penelitian, guru sudah melakukan kegiatan tindak lanjut dalam penggunaan media pembelajaran. Bentuk kegiatan tindak lanjut tersebut antara lain siswa menjawab pertanyaan dan mengerjakan lembar kegiatan yang ada pada buku tema, maupun diskusi bersama melalui zoom dengan siswa kelas V. Guru juga tidak lupa memberikan umpan balik kepada siswa terhadap hasil pengerjaan siswa melalui pesan whatsapp maupun secara langsung saat kegiatan zoom.

\subsection{Kendala Penerapan Media}

Guru mengalami kendala dalam penerapan media pada pembelajaran daring kelas V SDN Sumbersari 1 Malang. Kendala yang dialami oleh guru yaitu kemampuan guru dalam merancang media pembelajaran daring berbasis teknologi. Guru merasa terbantu dengan adanya media dan bahan ajar yang disusun bersama oleh KKG. Dalam pengadaan media berbasis teknologi guru masih membutuhkan bantuan orang lain untuk membantu mengedit video, memotong bagian video, dan sebagainya. Hal ini juga dijelaskan dalam Putri \& Citra (2019) bahwa kendala guru dalam merencanakan dan mengembangkan media meliputi pemilihan media yang sesuai dengan materi pembelajaran yang ada pada kurikulum serta kendala untuk merancang media berbasis teknologi. Merancang media berbasis teknologi memang tidak mudah, membutuhkan banyak pengalaman dan latihan.

Kendala yang dialami oleh guru dalam penerapan penggunaan media pada pembelajaran daring berdasarkan hasil wawancara yaitu terdapat siswa yang tidak membuka media pembelajaran yang dikirimkan. Siswa tidak membuka video pembelajaran, langsung mengerjakan tugas pada hari itu. Padahal di dalam video juga terdapat informasi tentang materi pembelajaran maupun kegiatan yang harus dilakukan. Hal ini mengakibatkan terdapat langkah-langkah dalam pembelajaran yang terlewatkan. Menurut Arsyad (2017) salah satu hal yang menjadi pertimbangan dalam penggunaan media yaitu partisipasi siswa. Kesempatan siswa untuk memahami dan mengingat materi pembelajaran dapat terbuka lebar apabila terjadi adanya partisipasi. Pembelajaran yang efektif bersifat menekankan pemberdayaan siswa secara aktif di dalam pembelajaran agar tertanam dan terinternalisasi dalam diri siswa tentang pengetahuan yang diperoleh (Fakhrurrazi, 2018).

Kendala penggunaan media selanjutnya ditemui pada saat kegiatan zoom. Berdasarkan hasil observasi, terdapat siswa yang terlambat mengikuti zoom dan tidak dapat masuk karena belum diadmit oleh guru kelas. Saat penjelasan melalui zoom terdapat siswa yang mencoreti layar tampilan powerpoint pada zoom. Sehingga tampilan pada powerpoint sempat terganggu oleh coretan tersebut. Kendala yang ditemukan selanjutnya, pada room chat yang ada pada zoom terdapat siswa yang ramai dengan mengirim pesan pada ruang tersebut. Hal ini membuat siswa lain terganggu dalam menyimak penjelasan guru. 


\section{Simpulan}

Berdasarkan hasil penelitian dapat disimpulkan bahwa dalam merencanakan penggunaan media, guru hanya mengacu pada media yang tertera pada RPP. Hanya terdapat 13 dokumen perencanaan media dan bukan merupakan hasil perencanaan sendiri melainkan dari KKG segugus. Dari 13 dokumen perencanaan media yang disusun, hanya terdapat 6 dokumen perencanaan media pembelajaran daring yaitu pada pembelajaran subtema 3. Media yang direncanakan masih kurang bervariasi karena 50\% lebih merupakan media teks dan gambar yang sudah tersedia pada buku tema 7 .

Pemilihan media pembelajaran daring pada tema 7 kelas V dilakukan sebanyak 6 kali pembelajaran. Media yang dipilih berbeda dengan media yang sudah direncanakan di dalam RPP. Guru sudah memperhatikan kriteria pemilihan media, namun terdapat media yang tidak sesuai dengan materi pembelajaran.

Media yang digunakan pada pembelajaran tema 7 sudah cukup bervariasi, tidak hanya menggunakan media yang sudah tersedia pada buku tema saja. Langkah-langkah penggunaan juga sudah diterapkan dengan baik. Guru tidak terlalu berpatokan pada dokumen perencanaan media yang ada. Perencanaan media yang tersedia dari gugus tidak diterapkan secara $100 \%$, dikarenakan kondisi pada setiap sekolah berbeda sehingga tidak dapat disamakan.

Kendala yang dialami oleh guru yaitu kemampuan guru dalam pengadaan media berbasis teknologi. Kendala dalam penerapan media pada pembelajaran daring yaitu terdapat siswa yang tidak membuka media pembelajaran yang dikirimkan. Kendala pada saat zoom yaitu terdapat siswa yang terlambat dan tidak dapat masuk zoom. Juga terdapat siswa yang ramai pada room chat dan mencoreti layar tampilan PPT sehingga sempat mengganggu konsentrasi siswa lainnya..

\section{Daftar Rujukan}

Abidin, Z. (2017). Penerapan Pemilihan Media Pembelajaran. Edcomtech Jurnal Kajian Teknologi Pendidikan, 1(1), 9-20.

Akbar, S. (2013). Instrumen Perangkat Pembelajaran. Bandung: PT Remaja Rosdakarya

Amelia, R. (2019). Penggunaan Media dalam Pembelajaran Tema 6 "Panas dan Perpindahannya” Kelas V di SDN Gadingkasri Kota Malang. Skripsi tidak diterbitkan. Malang: FIP UM

Arsyad, A. (2017). Media Pembelajaran. Jakarta: PT RajaGrafindo Persada

Daryanto. (2013). Media Pembelajaran: Peranannya Sangat Penting dalam Mencapai Tujuan Pembelajaran. Yogyakarta: Gava Media

Fakhrurrazi. (2018). Hakikat Pembelajaran yang Efektif. Jurnal At- Takfir, 11(1), 85-97.

Gusty, S., dkk. (2020). Belajar Mandiri: Pembelajaran Daring di Tengah Pandemi Covid-19. Yayasan Kita Menulis.

Hasnaini, I. (2017). Analisis Penggunaan Media Berdasarkan Kurikulum 2013 pada Pembelajaran Tema 6 Kelas V SDN Sawojajar 5 Kota Malang. Skripsi tidak diterbitkan. Malang: FIP UM

Musfiqon. (2016). Pengembangan Media dan Sumber Pembelajaran. Jakarta : PT Prestasi Pustakaraya

Moleong, L. J. (2017). Metodologi Penelitian Kualitatif. Bandung: PT Remaja Rosdakarya

Nurseto, T., (2012). Membuat Media Pembelajaran yang Menarik. Jurnal Ekonomi dan Pendidikan, 8(1), 19-34.

Putri, S. D., \& Citra, D. A. (2019). Problematika Guru dalam Menggunakan Media Pembelajaran Pada Mata Pelajaran IPS di MI Darussalam Kota Bengkulu. Indonesian Journal of Social Science Education, 1(1), 4953. 
Jurnal Pembelajaran, Bimbingan, dan Pengelolaan Pendidikan, 1(6), 2021, 419-429

Sadiman, A. S., Rahardjo, R., Haryono, A., \& Rahardjito. (2011). Media Pendidikan: Pengertian, Pengembangan, dan Pemanfaatannya. Jakarta: Rajawali Pers

Suryani, N., Setiawan, A., \& Putria, A. (2018). Media Pembelajaran Inovatif dan Pengembangannya. Bandung: PT Remaja Rosdakarya 